\title{
FAKTOR-FAKTOR YANG MEMPENGARUHI PEMBERIAN ASI EKSKLUSIF PADA IBU NIFAS DI WILAYAH KERJA PUSKESMAS BONTOBAHARI KABUPATEN BULUKUMBA
}

\author{
${ }^{1}$ Iramaya Sari \\ ${ }^{2}$ Aldina Lestari
}

${ }^{1}$ Program Studi DII Kebidanan, Stikes Panrita Husada Bulukumba

${ }^{2}$ Program Studi DIII Kebidanan, Stikes Panrita Husada Bulukumba

\author{
Alamat Korespondensi: \\ Iramaya Sari \\ Btn Iin Citra Lestari Blok B No.9 \\ Program Studi Ilmu Keperawatan \\ Sekolah Tinggi Ilmu Kesehatan Panrita Husada \\ Bulukumba, 04132514721 \\ Hp. 0852345609952 \\ Email: iramaya010185@gmail.com
}




\begin{abstract}
ABSTRAK
Asi merupakan sumber gizi yang sangat ideal dengan komposisi yang seimbang dan disesuaikan dengan kebutuh pertumbuhan bayi. Tujuan penelitian ini faktor-faktor pemberian ASI eksklusif pada ibu nifas primipara diwilayah kerja Puskesmas Bonto Bahari. Desain penelitian ini mengunnakan desain analitik dengan pendekatan crosssecsional. Jumlah populasi dan sampelpada penelitian ini yaitu 30 responden dengan menggunakan total sampling. Metode pengumpulan data yang diguanakan adalah lembar kuesioner. Dari hasi yang dilakukan peneliti didapatkan karakteristik responden dilihat dari usia sebagian besar responden memiliki usia 20-35 tahun sebanyak 28 responden,dan sebagian besar responden memilki tingkat pendidikan SD sebanyak 11 responden.data analisis univariat didapatkan sebagian responden memiliki pengetahun yang kurang sebanyak 50,0\% dan sebagian besar responden memilki pengaruh budaya yang tinggi sebesar 70,0\% sedangkan untuk dukungan tenga kesehatan sebagian responden memilki dukungan tenaga kesehatan yang baik sebesar 76,7\%dan sebagian besar responden tidak memberikan Asi kepada bayinya sebesar 86,7\%sedangkan analisis biavariat dengan menggunakan uji statistic chi square alternatif fisher. Hasil penelitian menunjukkan bahwa tingkat pengetahuan $(\mathrm{p}=0,008)$ dan pengaruh budaya $(\mathrm{p}=0,005)$ memiliki hubungan yang signifikan dengan pemberian ASI secara eksklusif sedangkan dukungan petugas kesehatan $(p=1,000)$ tidak memilki hubungan dengan pemberian ASI secara esklusif. Agar penelitian ini dapat memberikan informasi mengenai pemberian ASI eksklusif terutama ibu nifas dan menjadi masukan bagi petugas tenaga kesehatan di wilayah puskesmas gattareng dan juga berguna untuk semua pihak serta dapat menjadi referensi untuk penelitian selanjutnya
\end{abstract}

\title{
Kata kunci : ASI, Sumber Gizi, Ibu Nifas
}

\begin{abstract}
Asi is an ideal source of nutrition with a balanced composition and adapted to the needs of baby's growth. The purpose of this study was exclusive breastfeeding factors in primipara postpartum mothers in the Bonto Bahari Community Health Center work area. The design of this study employs analytical design with a cross-functional approach. The total population and sample in this study were 30 respondents using total sampling. The data collection method used is the questionnaire sheet. From the results of the research, it was found that the respondents' characteristics were seen from the age of the majority of respondents aged 20-35 years as many as 28 respondents, and the majority of respondents had an elementary education level of 11 respondents. \% and most respondents have a high cultural influence of $70.0 \%$ while for health support some respondents have good health personnel support of $76.7 \%$ and most respondents do not provide breast milk to their babies at $86.7 \%$ while biavariate analysis by using Fisher's alternative chi square statistical test. The results showed that the level of knowledge $(p=0.008)$ and cultural influence $(p=0.005)$ had a significant relationship with exclusive breastfeeding while the support of health workers $(p=1,000)$ did not have an association with exclusive breastfeeding. In order for this study to provide information about exclusive breastfeeding, especially postpartum mothers and become input for health workers in the area of Gattareng Health Center and also useful for all parties and can be a reference for future research
\end{abstract}

\section{Keywords: ASI, Source of Nutrition, Mother Nifas.}


PENDAHULUAN

ASI merupakan sumber gizi yang sangat ideal dengan komposisi yang seimbang dan disesuaikan dengan kebutuhan pertumbuhan bayi. Sedangkan ASI Eksklusif atau lebih tepatnya pemberian ASI secara eksklusif adalah bayi hanya diberi ASI saja, sampai usia 6 bulan, tanpa tambahan minuman atau makanan lain (Elisabeth dan Endang,2015).

Laporan WHO disebutkan bahwa hampir 90\% kematian balita terjadi di negara berkembang dan lebih dari $40 \%$ kematian disebabkan diare dan infeksi saluran pernapasan akut, yang dapat dicegah dengan ASI Eksklusif. WHO menyatakan sekitar $15 \%$ dari total kasus kematian anak di bawah usia lima tahun di negara berkembang disebabkan oleh pemberian ASI secara tidak eksklusif. Yang bisa menimbulkan berbagai masalah baik itu gizi kurang maupun gizi lebih.

The World Allience for Breastfeeding Action (WABA) memperkirakan 1 juta bayi dapat diselamatkan setiap tahunnya bila diberikan ASI pada 1 jam pertama kelahiran, kemudian dilanjutkan ASI Eksklusif sampai dengan 6 bulan, karena ASI selain mengandung gizi yang cukup, lengkap, juga mengandung imun untuk kekebalan tubuh bayi.(Nurleli,2017:2)
ASI Eksklusif merupakan makanan yang paling ideal bagi bayi. Oleh karena itu, pemerintah menetapkan target sekurangnya $80 \%$ ibu menyusui bayinya secara eksklusif. Kemudian pemerintah mengeluarkan kebijakan dalam Pasal 128 ayat (1) bahwa setiap bayi berhak mendapatkan Air Susu Ibu (ASI) Eksklusif sejak dilahirkan selama 6 bulan kecuali atas indikasi medis. Dalam penjelasan pasal ini disebutkan bahwa yang dimaksud dengan "pemberian air susu ibu eksklusif" adalah pemberian hanya air susu ibu selama 6 bulan,dan dapat terus dilanjutkan sampai dengan 2 (dua) tahun dengan memberikan makanan pendamping air susu ibu (MP-ASI) sebagai tambahan makanan sesuai dengan kebutuhan bayi. Sedangkan kriteria apakah "indikasi medis" itu dijelaskan bahwa yang dimaksud dengan "indikasi medis" dalam ketentuan ini adalah kondisi kesehatan ibu yang tidak memungkinkan memberikan air susu ibu berdasarkan indikasi medis yang ditetapkan oleh tenaga medis.(laily\&Retno,2017:1)

ASI Eksklusif adalah pemberian air susu ibu saja kepada bayi selama 6 bulan pertama kehidupan bayi tanpa memberikan makanan atau cairan lain kecuali vitamin, mineral dan obat yang telah diizinkan (WHO,2010). Berdasarkan data dari word Health Organization (WHO) pemberian ASI Eksklusif didunia pada tahun 2014 hanya 
mencapai $54 \%$ dari ibu nifas dan pemberian ASI eksklusif terendah terdapat di Negara berkembang. Di Negara berdasarkan buku tahun statistic ASEAN ( Association Of South East Asian Nations). Cakupan pemberian ASI eksklusif seperti di India sudah mencapai 46\%, di Philipina 34\%, di Vietnam 27\% dan di Myanmar 24\%, sedangkan di Indonesia sudah mencapai $52,3 \%$.

Data dari Riset Kesehatan Dasar tahun 2013 pemberian ASI saja 24 jam terakhir menurut umur 0 bulan sebanyak $52,7 \%$, umur 1 bulan $48,7 \%$, umur 2 bulan $46,0 \%$, umur 3 bulan $42,2 \%$, umur 4 bulan $41,9 \%$, umur 5 bulan $36,6 \%$ dan pada umur 6 bulan menurun sebanyak $30,2 \%$ dari data tersebut menunjukkan bahwa persentase pemberian ASI saja dalam 24 jam semakin menurun seiring meningkatnya umur bayi.

Data dari Profil Kesehatan Indonesia tahun 2015 menunjukkan secara nasional ibu yang menyusui bayinya secara eksklusif 0-6 bulan mencapai 55,7\% (Profil Kesehatan Indonesia tahun 2015, diakses pada tanggal 7 Mey 2018). Data dan Informasi profil kesehatan Indonesia tahun 2016 menunjukkan jumlah ibu yang menyusui bayinya kurang dari 1 jam sebanyak $42,7 \%$, yang menyusui lebih dari 1 jam 9,2\% dan yang menyusui $0-5$ bulan $54,0 \%$ dan yang menyusui bayinya secara eksklusif 0-6 bulan mencapai 29,5\% (Data dan Informasi profil kesehatan Indonesia 2016, diakses pada tanggal 7 Mey 2018)

Data Profil Dinas Kesehatan Provinsi Sulawesi Selatan tahun 2017, menyebutkan bahwa pemberian ASI Eksklusif pada tahun 2013 sebesar 62,70\%, tahun 2014 mengalami penurunan 56,31\%,tahun 2015 sebesar 59,14\% dan tahun 2016 sebesar 63,24 (Dinkes prov.sulawesi selatan,2017 di akses pada tanggal 7 Mei 2018)

Cakupan pemberian ASI eksklusif untuk dinas kabupaten Bulukumba pada tahun 2015 dari 7228 ibu nifas hanya 6890 yang mendapatkan ASI eksklusif dan yang tidak mendapatkan ASI eksklusif sebanyak 338, pada tahun 2016 dari 6268 ibu nifas hanya 5592 yang mendapatkan ASI eksklusif dan yang tidak mendapatkan ASI eksklusif sebanyak 676, dan pada tahun 2017 dari 6462 ibu nifas hanya 5678 yang mendapatkan ASI eksklusif dan yang tidak mendapatkan ASI eksklusif sebanyak 784

Data yang diperoleh dari puskesmas Bonto Bahari Kabupaten Bulukumba tahun 2015 dari 406 ibu nifas terdiri dari 235 multipara dan yang mendapatkan ASI Eksklusif 192 sedangkan yang tidak mendapatkan ASI eksklusif sebanyak 43 dan pada primi 171 dan yang mendapatkan ASI Eksklusif 98 sedangkan yang tidak mendapatkan ASI eksklusif sebanyak 73, 
pada tahun 2016 dari 408 ibu nifas terdiri dari 256 multipara dan mendapatkan ASI Eksklusif 213 sedangkan yang tidak mendapatkan ASI eksklusif 43 dan pada primi 152 dan yang mendapatkan ASI Eksklusif 86 sedangkan yang tidak mendapatkan ASI eksklusif sebanyak 66.

Pada tahun 2017 dari 396 ibu nifas terdiri dari 203 multipara dan yang mendapatkan ASI Eksklusif hanya 186 sedangkan yang tidak mendapatkan ASI eksklusif sebanyak 17 dan pada primi 193 dan yang mendapatkan ASI Eksklusif hanya 105 sedangkan yang tidak mendapatkan ASI eksklusif sebanyak 88 dan pada tahun 2018 bulan januari sampai april dari $128 \mathrm{ibu}$ nifas yang terdiri dari 73 multipara dan yang mendapatkan ASI Eklusif 62 sedangkan yang tidak mendapatkan ASI eksklusif sebanyak 11 dan pada primi 55 dan yang mendapatkan ASI Eksklusif hanya 29 orang sedangkan yang tidak mendapatkan ASI eksklusif sebanyak 26 orang.

Hasil penelitian Endah Puji Astuti (2017) Tingkat pengetahuan asi eksklusif pada ibu primipara di dusun pundong kelurahan srihardono kecamatan pundong Kabupaten bantul Berdasarkan hasil penelitian yang telah dilakukan, dapat diketahui bahwa tingkat pengetahuan ibu primipara tentang ASI eksklusif secara umum sebagian besar adalah kurang yaitu sebesar 36 responden $(60,0 \%)$ dan yang cukup $17(28,3 \%)$ dan sebagian kecil memiliki pengetahuan yang baik 7 responden $(11,7 \%)$.

Hasil penelitian Sri Mukhodim (2014) hubungan sosial budaya dengan pemberian ASI Eksklusif di posyandu desa sentul sidoarjo. Bahwa ibu yang tidak menyusui secara eksklusif dan sosial budayanya tinggi lebih banyak yaitu 20 orang sedangkan ibu yang sosial budayanya rendah sebanyak 7 orang. Hasil uji exact fisher ditemukan $\mathrm{p}=0,01$ dengan taraf signifikan 0,05 yang berarti H0 di tolak artinya ada hubungan antara sosial budaya dengan pemberian ASI secara Eksklusif .

Hasil penelitian Septian Emma Jatmika (2014) Dukungan tenaga kesehatan untuk meningkatkan niat ibu dalam memberikan ASI Eksklusif diwilayah kerja puskesmas Gondokusuman Kota Yogyakarta. Berdasarkan hasil tabulasi silang didapatkan gambaran bahwa responden yang mempunyai niat rendah dalam memberikan ASI Eksklusif, persentase terbesar pada responden yang dukungan tenaga kesehatan kurang yaitu sebesar $88,0 \%$. Sedangkan responden nilai tinggi yang mempunyai niat tinggi dalam memberikan ASI Eksklusif, persentase terbesar pada yang memiliki dukungan tenaga kesehatan baik yaitu sebesar 50,0\%. 
Hasil analisis Bivariat ada hubungan signifikan antara dukungan tenaga kesehatan dengan pemberian ASI secara Eksklusif dengan nialai $\mathrm{p}$ value 0,000 dengan taraf signifikan 0,05 .

Dari hasil wawancara yang dilakukan kepada 30 orang nifas primipara didapatkan 7 orang berpengetahuan baik, 8 orang berpengetahuan cukup dan 15 orang yang berpengetahuan kurang, sehingga masih banyak ibu yang tidak mengetahui pentingnya pemberian ASI Eksklusif karena tidak adanya pengalaman menyusui sebelumnya, dan ibu menganggap ASI belum keluar pada hari pertama sehingga bayi dianggap perlu diberikan minuman tambahan, ibu merasa ASI-nya kurang, padahal sebenarnya cukup hanya saja ibu yang kurang yakin dapat memproduksi ASI yang cukup.dan memberikan air beras kepada bayi dipercaya dapat menghindarkan bayi dari teguran nenek moyang yang terdahulu.

Berdasarkan hal tersebut maka peneliti tertarik mengadakan penelitian dengan judul " Faktor-Faktor Pemberian ASI Eksklusif Ibu Nifas Diwilayah Puskesmas Bonto Bahari Tahun 2018”

\section{METODE PENELITIAN}

Desain penelitian adalah model atau metode yang digunakan peneliti untuk melakukan suatu tindakan penelitian yang memberikan arah terhadap jalannya penelitian ini adalah penelitian analitik dengan pendekatan cross sectional karena penelitian ini bertujuan untuk mengetahui hubungan antara variabel independen dengan variabel dependen. Variabel yang diteliti yaitu faktor-faktor yang mempengaruhi pemberian ASI eksklusif pada ibu nifas primipara di wilayah kerja Puskesmas BontoBahari.

Populasi dalam penelitian adalah semua ibu nifas primipara di wilayah kerja puskesmas Bonto Bahari kecamatan gantarang kabupaten bulukumba yaitu sebanyak 30 orang .Sampel adalah bagian dari populasi yang akan di teliti atau sebagian jumlah dari karakteristik yang dimiliki oleh populasi yaitu 30 ibu nifas. Untuk mendapatkan sampel penelitian dilakukan berdasarkan kuesioner yang diberikan pada ibu nifas primipara, melakukan kunjungan kerumah-rumah di wilayah kerja Puskesmas Bonto Bahari Kabupaten Bulukumba Tahun 2018.

\section{HASIL}

Tabel 1, menunjukkan bahwa sebagian besar responden memiliki usia antara 20-35 tahun sebanyak 28 orang(93,3\%), sedangkan yang memiliki usia $<20$ tahun sebanyak 2 orang $(6,7 \%)$. Sedangkan dilihat dari pendidikan 
responden sebagian besar memiliki pendidikan SD sebanyak 11 orang $(36,6 \%)$, SMP sebanyak 2 orang $(6,6 \%)$, SMA sebanyak 8 orang $(26,6 \%)$, dan perguruan tinggi 9 orang $(30,2 \%)$. Tabel 2 menunjukkan hasil penelitian di wilayah kerja Puskesmas Bonto Bahari dapat diketahui bahwa sebagian besar ibu nifas primipara memiliki tingkat pengetahuan kurang sebesar 15 orang (50,0\%), dan yang berpengetahuan baik hanya 10 orang $(33,3 \%)$, sedangkan yang berpengetahuan cukup hanya 5 orang $(16,7 \%)$. Tabel 3 , dari hasil penelitian di wilayah kerja Puskesmas Bonto Bahari dapat diketahui bahwa sebagian besar ibu nifas primipara memiliki pengaruh budaya yang tinggi sebanyak 21 orang $(70,0 \%)$, sedangkan yang mempunyai pengaruh budaya rendah sebanyak 9 orang $(30,0 \%)$

Tabel 4, menunjukkan hasil penelitian dapat disimpulkan bahwa dukungan petugas kesehatan terhadap ibu nifas primipara tentang pemberian ASI eksklusif cukup baik yaitu sebesar 76,7\% (23 orang), dan kurang sebesar $23,3 \%$ (7 orang). Tabel 5, menunjukkan hasil penelitian di Wilayah kerja puskesmas Bonto Bahari tentang pemberian ASI eksklusif. Jika dihitung dalam bentuk persentase, maka diketahui bahwa terdapat $86,7 \%$ (26 orang) yang tidak memberikan ASI secara eksklusif pada bayinya dan $13,3 \%$ (4 orang) yang memberikan ASI secara Ekslusif kepada bayinya.

Tabel 6, Dari hasil uji chi square yang dilakukan terhadap tingkat pengetahuan ibu tentang ASI eksklusif pada responden dengan pemberian ASI secara Eksklusif di wilayah kerja Puskesmas Bonto Bahari dengan nilai $p$ value sebesar 0,008 dengan taraf signifikan 0,05 maka nilai p lebih kecil dari pada taraf signifikan $(0,008<0,05)$. Maka kesimpulan yang dapat diambil bahwa Ha diterima dan Ho di tolak, yang mempunyai arti bahwa ada hubungan yang signifikan antara tingakat pengetahuan ibu tentang ASI eksklusif dengan pemberian ASI secara eksklusif pada masa nifas di wilayah kerja puskesmas Gattareng

Tabel 7 dari hasil uji chi square dengan alternatif fisher yang dilakukan terhadap pengaruh budaya pada responden dengan pemberian ASI secara Eksklusif di wilayah kerja puskesmas Gattareng dengan nilai $\mathrm{p}$ value sebesar 0,005 dengan taraf signifikan 0,05 maka nilai $\mathrm{p}$ lebih kecil dari pada taraf signifikan $(0,005<0,05)$. Maka kesimpulan yang dapat diambil bahwa $\mathrm{Ha}$ diterima dan Ho di tolak, yang mempunyai arti bahwa ada hubungan yang signifikan antara pengaruh budaya dengan pemberian ASI secara eksklusif pada masa nifas di wilayah kerja puskesmas Gattareng 
Tabel 8 dari hasil uji chi square dengan alternatif fisher yang dilakukan terhadap dukungan petugas kesehatan pada responden dengan pemberian ASI secara Eksklusif di wilayah kerja puskesmas Gattareng dengan nilai $\mathrm{p}$ value sebesar 1,000 dengan taraf signifikan 0,05 maka nilai $\mathrm{p}$ lebih besar dari pada taraf signifikan $(1,000>0,05)$. Maka kesipulan yang dapat diambil bahwa H0 diterima dan Ha di tolak, yang mempunyai arti bahwa tidak ada hubungan yang signifakan antara dukungan petugas kesehatan dengan pemberian ASI secara eksklusif pada masa nifas di wilayah kerja puskesmas Gattareng.

\section{PEMBAHASAN}

Berdasarkan hasil penelitian di wilayah kerja puskesmas Gattareng, ada hubungan yang signifikan antara tingkat pengetahuan ibu tentang ASI eksklusif dengan pemberian ASI secara eksklusif, jadi dalam hal ini hipotesis kerja di terima, yang berarti bahwa semakin baik tingkat pengathuan ibu maka semakin baik kesadaran ibu untuk memberikan ASI secara eksklusif. Sebagian besar ibu nifas primipara yang ada diwilayah kerja puskesmas Gattareng sebagian besar mempunyai pengetahuan kurang sebanyak 15 orang (50,0\%)dan tidak memberikan ASI secara eksklusif sedangkan yang berpengetahuan baik sebanyak 10 orang sedangkan yang memberikan ASI eksklusif hanya 4 orang, hal ini juga dipengaruhi oleh status pendidikan ibu maupun usia ibu . Hal ini terutama tercermin dari pengetahuan ibu terhadap manfaat ASI dan pengetahuan ibu tentang pemberian makanan tambahan pada usia kurang dari 6 bulan.

Hasil penelitian ini sesuai dengan teori notoatmodjo (2010), ibu yang memiliki pengetahuan kurang cenderung memiliki perilaku yang kurang baik dalam perilakunya. Semakin tinggi pengetahuan ibu maka semakin besar kemungkinannya untuk memberikan ASI secara eksklusif. Hal ini disebabkan karena pengetahuan ibu juga dipengaruhi oleh pendidikan, pengalaman dan informasi yang didapat ibu tentang ASI eksklusif. Pengetahuan atau kognitif merupakan hal yang sangat penting dalam membentuk tindakan seseorang, salah satunya kurang memadainya pengetahuan ibu mengenai pentingnya ASI eksklusif yang menjadikan penyebab atau masalah dalam peningkatan pemberia ASI secara eksklusif. Salah satu faktor yang mempengaruhi pengetahuan adalah tingkat pendidikan yaitu semakin tinggi tingkat pendidikan ibu maka akan semakin baik pula pengetahuan ibu, dan umur juga mempengaruhi pengetahuan seseorang, jika seseorang memiliki umur yang cukup maka akan memiliki pola pikir 
yang matang, umur sangat berpengaruh terhadap daya tangkap sehingga pengetahuan diperoleh akan semakin baik.

Berdasarkan hasil penelitian yang telah dilakukan,oleh Endah Puji Astuti (2017) di dusun pundong kelurahan srihardono kecamatan pundong kabupaten Bantul dapat diketahui bahwa tingkat pengetahuan ibu primipara tentang ASI eksklusif secara umum sebagian besar adalah kurang yaitu sebesar 36 responden $(60,0 \%)$ dan sebagian kecil memiliki pengetahuan yang baik 7 responden (11,7\%). Begitu halnya dengan tingkat pengetahuan ibu primipara tentang definisi ASI, didapatkan hasil sebagian besar responden berpengetahuan kurang yaitu 41 responden $(68,3 \%)$ dan sebagian kecil berpengetahuan baik yaitu 9 responden $(15,0 \%)$, diketahui pertanyaan yang paling tidak bisa dijawab oleh responden adalah pertanyaan tetap ASI eksklusif meskipun bayi diberikan air putih, madu atau teh, sebagian besar responden menjawab benar, jawaban tersebut menunjukkan bahwa memberikan makanan atau minuman sebelum bayi berusia 6 bulan mereka anggap tetap ASI eksklusif.

Asumsi peneliti mengatakan bahwa dari hasil penelitian yang dilakukan di wilayah kerja puskesmas gattareng terdapat hubungan antara pengetahuan ibu dengan status pemberian ASI secara Eksklusif jadi dapat dikatakan bahwa ibu yang berpengetahuan baik cenderung memberikan ASI kepada bayinya dibanding ibu yang berpengetahuan cukup maupun kurang. Sedangkan ibu yang memiliki pengetahuan baik namun tidak melakukan pemberian ASI secara eksklusif disebabkan karena ketersediaan ASI yang kurang, dan pengaruh budaya sehingga tidak memberikan ASI secara eksklusif.

Pengetahuan ibu tentang ASI eksklusif dapat mempengaruhi ibu dalam memberikan ASI secaara eksklusif. Semakin baik pengetahuan ibu tentang manfaat ASI eksklusif , maka seorang ibu akan memberikan ASI secara eksklusif pada anaknya. Begitu juga sebaliknya, semakin rendah pengetahuan ibu tentang ASI eksklusif maka semaking sedikit pula peluang ibu dalam memberikan ASI eksklusif.

Adat budaya akan mempengaruhi ibu untuk memberikan ASI secara eksklusif karena sudah menjadi budaya dalam keluarganya. Salah satu adat budaya yang masih banyak dilaakukan di masyarakat yaitu adat selapanan, dimana bayi diberi sesuap bubur dengan alasan untuk melatih alat pencernaan bayi. Padahal hal tersebut tidak benar, namun tetap dilakukan oleh masyarakat karena sudah menjadi adat 
budaya dalam keluarganya.(Elisabeth \& Endang,2015)

Hasil penelitian Sri Mukhodim (2014) hubungan sosial budaya dengan pemberian ASI Eksklusif di posyandu desa sentul sidoarjo. Bahwa ibu yang tidak menyusui secara eksklusif dan sosial budayanya tinggi lebih banyak yaitu 20 orang sedangkan ibu yang sosial budayanya rendah sebanyak 7 orang.setelah dilakukan uji Exact fisher didapatkan hasil ada hubungan antara sosial budaya dengan pemberian ASI secara eksklusif. Menurut Soetjiningsih (2006) dalam penelitian tersebut menyatakan bahwa meniru teman, tetangga atau orang yang terkemuka yang memberikan susu botol merupakan persepsi masyarakat akan hidup mewah, membeawa dampak kesediaan ibu untuk menyusui bayinya.

Hal ini sesuai dengan hasil penelitian yang dilakukan di wilayah kerja puskesmas Gattareng, dapat diketahui bahwa responden yang mempunyai pengaruh budaya yang tinggi tidak memberikan ASI secara Eksklusif kepada bayinya yaitu sebayak 21 orang dan yang memiliki pengaruh budaya rendah memberikan ASI secara Ekslusif kepada bayinya sebanyak 4 orang sedangkan yang tidak memberikan ASI secara Eksklusif sebanyak 5 orang, sebagian besar ibu memiliki kebiasaan memberikan air, madu, tambahan lain sebelum bayi berusia 6 bulan.

Hal ini menunjukkan bahwa ada hubungan yang signifikan antara pengaruh budaya dengan pemberian ASI secara eksklusif

Asumsi peneliti mengatakan bahwa dari hasil penelitian yang dilakukan di wilayah kerja puskesmas gattareng terdapat hubungan antara pengaruh budaya dengan status pemberian ASI secara eksklusif jadi dapat dikatakan bahwa ibu yang memiliki budaya yang tinggi cenderung tidak memberikan ASI secara eksklusif kepada bayinya debandingkan dengan ibu yang memiliki budaya yang rendah, namun adapun ibu yang tidak dipengaruhi oleh budaya namun tidak memberikan ASI secara eksklusif dikarenakan oleh kondisi ibu yang melahirkan secara operasi, dan ASI yang tidak lancar.

Semakin tinggi pengaruh budaya ibu maka sedikit pula peluang ibu untuk memberikan ASI secara eksklusif kepada bayinya, sebaliknya semakin rendah pengaruh budaya ibu maka semakin tinggi peluang ibu untuk memberikan ASI secara eksklusif kepada bayinya.

Dari hasil penelitian ini, dapat diketahui bahwa responden yang mempunyai dukungan petugas kesehatan dalam kategori baik yang memberikan ASI secara Eksklusif sebanyak 3 orang dan yang tidak 
memberikan ASI secara eksklusif sebanyak 20 orang. Responden yang mempunyai dukungan petugas kesehatan yang kurang dan memberikan ASI eksklusif sebnyak 1 orang dan yang tidak memberikan ASI secara Eksklusif sebanyak 6 orang. Dari hasil uji chi square dengan alternatif fisher yang dilakukan terhadap dukungan petugas kesehatan pada responden dengan pemberian ASI secara Eksklusif di wilayah kerja puskesmas Gattareng menujukkan bahwa tidak ada hubungan antara dukungan petugas kesehatan dengan pemberian ASI secara Eksklusif.

Berbeda dengan hasil penelitian Septian Emma Jatmika (2014) Dukungan tenaga kesehatan untuk meningkatkan niat ibu dalam memberikan ASI Eksklusif diwilayah kerja Puskesmas Gondokusuman Kota Yogyakarta. Berdasarkan hasil tabulasi silang didapatkan gambaran bahwa responden yang mempunyai niat rendah dalam memberikan ASI Eksklusif, persentase terbesar pada responden yang dukungan tenaga kesehatan kurang yaitu sebesar $88,0 \%$. Sedangkan responden nilai tinggi yang mempunyai niat tinggi dalam memberikan ASI Eksklusif, persentase terbesar pada yang memiliki dukungan tenaga kesehatan baik yaitu sebesar 50,0\%. Dari hasil uji statistik menunjukkan bahwa ada hubungan antara dukungan petugas kesehatan dengan pemberian ASI secara Eksklusif. Hal ini dikarenakan pada dasar nya dalam penelitian ini menunjukkan dukungan petugas kesehatan memang kurang, berbeda dengan hasil penelitian yang dilakukan diwilayah kerja puskesmas Bonto Bahari menunjukkan dukungan petugas kesehatan baik.

Hal ini menunjukkan bahwa dukungan petugas kesehatan yang baik tidak menjamin untuk mengubah perilaku ibu dalam pemberian ASI secara eksklusif. Dalam teori yang dikemukakan oleh Elizabeth \& Endang (2015) bahwa faktor pendorong (reinforcing faktor) terbagi dua, yang pertama dukungan keluarga dan yang kedua dukungan petugas kesehatan.

Asumsi peneliti mengatakan bahwa dari hasil penelitian yang dilakukan diwilayah kerja puskesmas gattareng tidak ada hubungan antara dukungan petugas kesehatan dengan status pemberian ASI secara eksklusif dikarenakan pengaruh budaya yang begitu tinggi sehingga mempengaruhi dukungan petugas kesehatan. Hal ini dapat disimpulkan bahwa sebaik apapun dukungan tenaga kesehatan terhadap pemberian ASI eksklusif namun tidak sejalan dengan dukungan keluarga maka tidak akan mengubah perilaku ibu dalam pemberian ASI eksklusif. 
Di karenakan dukungan dari lingkungan keluarga termasuk suami, orang tua atau saudara lainnya sangat menentukan keberhasilan menyusui. Karena pengaruh keluarga berdampak pada kondisi emosi ibu sehingga secara tidak langsung mempengaruhi produksi ASI. Seorang ibu yang mendapatkan dukungan dari suami dan anggota keluarga lainnya akan meningkatkan pemberian ASI kepada bayinya. Sebaliknya dukungan yang kurang maka pemberian ASI menurun. Hasil penelitian-penenlitian terdahulu juga menunjukkan pentingnya dukungan dari keluarga terhadap ibu menyusui, terutama dukungan suami karena suami adalah seseorang yang dekat dengan ibu.

\section{KESIMPULAN}

Agar penelitian ini dapat memberikan informasi mengenai pemberian ASI eksklusif terutam ibu nifas primipara dan menjadi masukan bagi petugas tenaga kesehatan di wilayah puskesmas BontoBahari dan juga berguna untuk semua pihak serta dapat menjadi referensi untuk penelitian selanjutnya

\section{DAFTAR PUSTAKA}

Astuti, E. P., \& Fara Adhiba. (2017). Tingkat Pengetahuan Asi Eksklusif Pada Ibu Primipara Di Dusun Pundong
Kelurahan Srihardono Kecamatan Pundong. Program Studi D3Kebidanan STIKES A. Yani Yogyakarta, 1.

Buku Acuan Midwifery Update,2016

Haryono, R., \& Sulis Setianingsih. (2014). Manfaat ASI Eksklusif Untuk Buah Hati Anda. Yogyakarta: Gosyen Publishing.

Himawati, L., \& Retno Mawarti. (2011). Pengaruh pendidikan kesehatan tentang teknik menyusui terhadap pengetahuan dan perilaku teknik menyusui pada ibu primipara. Aisyiyah Yogyakarta, 1-2.

Indriyani, D. (2013). Aplikasi Konsep \& Teori Keperawatan Maternitas Postpartum Dengan Kematian Janin. Yogyakarta: Ar-Ruzz Media.

Informasi Profil Kesehatan Indonesia 2016 ( diakses pada tanggal 7 mey 2018)

Iswandari, N. D., Agus Muliawan, \& Dewi Astuti. (2015). Gambaran pengetahuanibu nifas normal 1-3 hari tentang pemberian kolostrumdi ruang nifas di rsud dr. H. Moch. Ansari saleh banjarmasin. Stikes Sari Mulia Banjarmasin, 1.

Jatmika. E. S. (2014) . Dukungan tenaga kesehatan untuk meningkatkan niat ibu dalam memberikan asi eksklusif diwilayah kerja puskesmas 
gondokusuma kota yogyakarta. Prawirohardjo, S. (2014). Ilmu kebidanan. Jurnal Promosi Kesehatan Indonesia Vol.9/No.2/ Agustus 2014 Jakarta: P.T.Bina Pustaka.

Riset Kesehatan Dasar 2013 (Di akses pada Lowdemilk, Perry, \& Cashion. (2013). tanggal 8 mey 2018)

Keperawatan Maternitas. Singapura: Elsevier.

Maritlia, D. (2012,2014). Asuhan Kebidanan Nifas Dan Menyusui. Yogyakarta: Pustaka Pelajar.

Mukhodim sri. (2014). Hubungan sosial budaya dengan pemberian asi eksklusif diposyandu desa sentul sidoarjo. Universitas muhammadiyah sidoardjo, 62-63.

Nirwana, A. B. (2014). Asi dan Susu Formula. Yogyakarta: Nuha Medika.

Notoatmodjo, S. (2012). Metode Penelitian Kesehatan. Jakarta: Rineka Cipta.

Nurleli, Jenny Marlindawani Purba, \& Rinawati Sembiring. (2018). Hubungan Pengetahuan Dan Sikap Ibu Dengan Tindakan Pemberian Asi Eksklusif Di Puskesmas Rambung Kecamatan Binjai Selatan Kota Binjai Tahun 2017. Jurnal Riset Hesti Medan, Vol. 3, No. 1, 2.

Profil Kesehatan Indonesia 2015 ( Di akses pada tanggal 7 mey 2018

Profil Dinas Kesehatan Provinsi Sulawesi Selatan 2017 ( Di akses tanggal 7 mey 2018) 
Tabel 1

Karakterisitik Responden Pemberian Asi Eksklusif Pada Ibu Nifas Di Wilayah Kerja Puskesmas Bontobahari

\begin{tabular}{lcc}
\hline \multicolumn{1}{c}{ Usia } & Frekuensi & Persentase (\%) \\
\hline$<20$ Tahun & 2 & $6,7 \%$ \\
20-35 tahun & 28 & $93,3 \%$ \\
$>35$ tahun & 0 & 0 \\
& & \\
\hline \multicolumn{1}{c}{ Pendidikan } & Frekuensi & Persentase $(\%)$ \\
\hline SD & 11 & $36,7 \%$ \\
SMP & 2 & $6,7 \%$ \\
SMA & 8 & $26,7 \%$ \\
PT & 9 & $30,0 \%$ \\
Total & 30 & $100 \%$ \\
\hline
\end{tabular}

Tabel 2

Tingkat pengetahuan Pemberian Asi Eksklusif

Pada Ibu Nifas Di Wilayah Kerja Puskesmas Bontobahari

\begin{tabular}{lcc}
\hline \multicolumn{1}{c}{ Pengetahuan } & Frekuensi & Persentase ( \%) \\
\hline Baik & 10 & $33,3 \%$ \\
Cukup & 5 & $16,7 \%$ \\
Kurang & 15 & $50,0 \%$ \\
\hline Total & 30 & $100 \%$ \\
\hline
\end{tabular}

Tabel 3

Budaya Pemberian Asi Eksklusif

Pada Ibu Nifas Di Wilayah Kerja Puskesmas Bontobahari

\begin{tabular}{lcc}
\hline Budaya & Frekuensi & Persentase $(\%)$ \\
\hline Tinggi & 21 & $70,0 \%$ \\
Rendah & 9 & $30,0 \%$ \\
\hline Total & 30 & $100 \%$ \\
\hline
\end{tabular}

Tabel 4

Dukungan Petugas Kesehatan Pemberian Asi Eksklusif Pada Ibu Nifas Di Wilayah Kerja Puskesmas Bontobahari

\begin{tabular}{lccc}
\hline $\begin{array}{l}\text { Dukungan } \\
\text { kesehatan }\end{array}$ & petugas & Frekuensi & Persentase (\%) \\
\hline Baik & 23 & $76,7 \%$ \\
Kurang & 7 & $23,3 \%$ \\
\hline Total & 30 & $100 \%$ \\
\hline
\end{tabular}


Tabel 5

Pemberian ASI Eksklusif Pada Ibu Nifas di Wilayah Kerja Puskesmas Bontobahari

\begin{tabular}{|c|c|c|}
\hline $\begin{array}{c}\text { Pemberian ASI } \\
\text { Eksklusif }\end{array}$ & Frekuensi & Persentase (\%) \\
\hline Ya & 4 & $13,3 \%$ \\
\hline Tidak & 26 & $86,7 \%$ \\
\hline Total & 30 & $100 \%$ \\
\hline
\end{tabular}

Tabel 6

Hubungan tingkat pengetahuan dengan pemberian ASI secara eksklusif

\begin{tabular}{|c|c|c|c|c|}
\hline \multirow[t]{2}{*}{$\begin{array}{l}\text { Tingkat } \\
\text { pengetahuan }\end{array}$} & $\begin{array}{l}\text { Pemberian } \\
\text { eksklusif pada } \\
\text { nifas }\end{array}$ & $\begin{array}{r}\text { ASI } \\
\text { masa }\end{array}$ & Total & Nilai $p$ \\
\hline & $\mathrm{Ya}$ & Tidak & & \\
\hline Baik & 4 & 6 & 10 & \\
\hline Cukup & 0 & 5 & 5 & 0,008 \\
\hline Kurang & 0 & 15 & 15 & \\
\hline Total & 4 & 6 & 30 & \\
\hline
\end{tabular}

Tabel 7

Hubungan pengaruh Budaya dengan pemberian ASI secara eksklusif

\begin{tabular}{lcccc}
\hline Budaya & $\begin{array}{l}\text { Pemberian } \\
\text { pada masa nifas }\end{array}$ & eksklusif & Total & Nilai p \\
\cline { 2 - 3 } Tinggi & Ya & Tidak & & \\
Rendah & 0 & 21 & 21 & 0,005 \\
\hline Total & 4 & 5 & 9 & \\
\hline
\end{tabular}

Tabel 8

Hubungan dukungan petugas kesehatan dengan pemberian ASI secara eksklusif

\begin{tabular}{|c|c|c|c|c|}
\hline $\begin{array}{l}\text { Dukungan } \\
\text { petugas } \\
\text { kesehatan }\end{array}$ & $\begin{array}{l}\text { Pemberian } \\
\text { eksklusif } \\
\text { nifas }\end{array}$ & $\begin{array}{rr}\text { ASI } \\
\text { pada masa }\end{array}$ & Total & Nilai $p$ \\
\hline & $\mathrm{Ya}$ & Tidak & & \\
\hline Baik & 3 & 20 & 23 & 1,000 \\
\hline Kurang & 1 & 6 & 7 & \\
\hline Total & 4 & 26 & 30 & \\
\hline
\end{tabular}

